\title{
Chapter 1 \\ Challenges for Future Monetary Policy Frameworks: A European Perspective
}

\author{
Vítor Constâncio*
}

Luncheon speeches should be thought-provoking and entertaining. Unfortunately, that's a dual mandate that's beyond the ability of this central banker to deliver. But if I cannot provide entertainment, allow me to at least provide some thoughts to hopefully provoke some discussion over our meal. To do this, allow me to deviate a little from the main theme of the conference and turn to another topic of common interest. In a cursory and compressed way, I would like to make some remarks on the ongoing debate about the future of monetary policy frameworks, a subject that has become quite topical here in the US.

We are now nine years after the beginning of the financial crisis. Considering the role of an overstretched monetary policy to stave off a deeper recession, the following questions were bound to emerge: has monetary policy done enough, should it continue along the same path? Are low, or even negative, rates a permanent feature of monetary policy? Should the size and composition of the central bank balance-sheet continue to be used as an unconventional tool? Should the flexible inflation targeting regime continue to be the dominant framework? Should the target for inflation be

\footnotetext{
* Vítor Constâncio is Vice-President of the European Central Bank. These comments were provided in a keynote speech at the 19th Annual International Banking Conference, Chicago, 4 November 2016.
} 
increased, or should we adopt a nominal GDP or price-level target instead? Should monetary policy closely follow a concrete rule like, for instance, a Taylor Rule? Should we assume a neo-Fisherian framework and admit that there are multiple economic equilibria and that rates should be increased to avoid leaving the economy stuck in a low-level one? Should the operational implementation of monetary policy go beyond short-term market rates or beyond banks as counterparties? Finally, have these questions a different meaning when addressed from Europe or from the US?

These questions are at the forefront of central banking discussion at present, as evidenced by the Jackson Hole gathering this year. They are also debated by academia, the blogosphere, and at official conferences. Be reassured, though, I will not address most of them at this occasion. The topic is too vast and my remarks would be scattered and incomplete. Instead, I will focus on the questions surrounding the choice of target and the choice of instruments.

The debate is, unsurprisingly, more advanced here in the US than in Europe, given the stronger recovery and policy normalization already under way. Logically, this raises questions about the future use of unconventional instruments and the efficiency of policy regimes to deal with a possible future recession.

The debate is embryonic in Europe, as the recovery remains moderate, with economic growth and inflation only recently starting to gain momentum. Furthermore, the debate will necessarily be more constrained given that the ECB's hierarchical mandate, defined in primary law, confers absolute primacy to price stability over other secondary objectives.

In fact, the debate about the dominant monetary policy regime Flexible Inflation Targeting (FIT) - started immediately after the emergence of the crisis. There were doubts about whether the narrow objective of monetary policy had allowed the crisis to develop by not reacting to the signs of financial instability and asset price booms. The question about the integration of financial stability concerns into the objective function of monetary policy has stayed with us, in spite of the fragile consensus that such concerns should be the purview of macroprudential policy.

More recently, further doubts about FIT arose over the inability of monetary policy to engineer a quicker recovery, strong enough to bring the economy back to its previous trend. Besides placing too much faith in 
monetary policy, this also opens the discussion about the targets of monetary policy.

\section{Changing central banks' targets}

In that discussion, a popular proposal is to adopt a target for nominal GDP. There are clear merits to nominal income targeting from a theoretical perspective, since it is a close approximation to the optimal policy prescribed by standard macroeconomic models. Under perfect credibility, such a target is fully consistent with maintaining price stability in the medium run (Woodford, 2012).

The proposal made by Meade, back in 1978, has had many illustrious supporters (Meade, 1978). It offers the rationale to accommodate cost or supply side shocks that impact inflation and would have led to more expansionary policies since the crisis to counter the growing GDP deviation from the previous growth trend. The proposal faces, however, considerable practical difficulties: from GDP data that is untimely and prone to revision to the demanding task of communicating to the public about a concept they do not directly experience. Another implementation obstacle relates to uncertainty over potential output, which risks nominal GDP targets delivering higher inflation without any benefit for real economic activity.

That said, as shown for instance by Charles Bean (2009) the practical difference between nominal GDP targeting and inflation targeting is not substantial. FIT permits policymakers to look through short-term supply shocks, and monetary policy would be similarly accommodative in the case of aggregate demand shocks under either type of target. Long ago, Lars Svensson showed how FIT, by aiming to return to the target only gradually, is equivalent to the use of an objective function with both inflation and the output gap (Svensson, 1997).

Finally, it is not easy for monetary policy to deliver a nominal income target. The enthusiasm of the supporters of the market monetarism school - believing that monetary aggregates could do the job — stands out as empirically unfounded.

So while a nominal income target may be theoretically superior, I remain very skeptical of its practical use, above and beyond the legal constraints that inhibit its adoption in the euro area. 
A concept that seems close to a nominal income target is the adoption of a type of Taylor rule to conduct monetary policy. Lars Svensson would insist on the distinction between a targeting rule and an instrument rule, which is a formula for setting the central bank's instrument rate as a function of target variables. He has pointed out the shortcomings of the latter (Svensson, 2003).

Benhabib et al. (2001) have also showed how Taylor rules combined with a zero lower bound would lead to multiple equilibria. It is not by chance that no central bank has ever committed to following an instrument rule.

The problem of the lower bound on interest rates led some economists (Blanchard et al., 2010) to propose an increase in the inflation target to create more room above the lower bound to respond to future recessionary episodes. However, changing the inflation objective at a time when outcomes have been below the current objective for a number of years risks damaging central banks' credibility. Changing the objective, say to 4 percent, would only be effective if inflation expectations were successfully reanchored at the higher level, which would be unattainable in present circumstances.

\section{Changing the policy instruments: Negative rates}

Turning now to the domain of instruments, let me start with negative interest rates, which have been used across Europe. The central bank deposit rate is negative in the euro area, Switzerland, and Sweden, with the main Swedish policy rate also negative. Negative rates have been effective in lowering the whole spectrum of short-term rates, and also at longer maturities via expectations. In this perspective, it has been a good complement to quantitative easing $(\mathrm{QE})$.

The intention behind the policy has always been temporary - to boost aggregate demand, closing the output gap more quickly, helping to normalize inflation, and subsequently interest rates. Only if central banks were to allow prolonged deflation could negative rates be considered a permanent instrument. Outside such an environment, the accumulated negative spillovers of negative rates on the profitability of financial institutions, and the interference on the role of monetary and 
financial assets as a store of value, would be unacceptable. The long-term consequences of an environment with low but positive inflation and negative rates would become too severe for the financial sector, savers, and pensioners.

In the short term though, ECB research has shown that the effect on the profitability of financial institutions has been overall positive, as they benefited from capital gains associated with asset price increases and, in the case of banks, from lower funding and impairment costs (Rostagno et al., 2016).

These effects, however, decline with time and are likely to fade out at some point.

In spite of these shortcomings, there are several economists supporting the idea that negative rates should be used practically without limit, and for that to be possible, they propose to abolish cash altogether (see Rogoff, 2016), ${ }^{1}$ which has some theoretical benefits. Monetary policy would no longer be constrained by the lower bound, providing ample room for maneuver to counteract severe cyclical downturns. Banks would be free to reduce their deposit rates, without the fear of customers withdrawing their money, and to increase their net interest margins. Abolishing cash would also hamper some illegal activities and improve transparency. Finally, society would benefit economically from eliminating the non-trivial costs of storing and using cash. Also theoretically, as all economic agents are supposed to think in real terms, further decreasing negative rates should be equivalent to reducing positive rates (Goodfriend, 2016).

Money illusion, however, is more widespread than economists presume. There are important drawbacks that raise concerns about this proposal. While eliminating certain illegal activities is desirable, people should have the right to privacy on their legal activities, on which full transparency to governments and, more importantly, to businesses would be unwarranted and intrusive. Furthermore, as already mentioned, money should continue to perform its function of store of value,

\footnotetext{
${ }^{1}$ The idea to abolish currency and move completely to electronic cash has been suggested at various times by other economists.
} 
which the ability to impose negative interest rates clearly violates outside continuous deflation.

In the light of all these uncertainties, a prudent policymaker would advise to be very cautious before proceeding with these radical proposals, even if digitalization may gain ground and finally prevail — as we start to observe in some countries.

\section{Changing the policy instruments: Size and composition of balance sheets}

Traditionally, central banks used short-term interest rates to steer the economy, and the pre-crisis wisdom was to use as lean a balance sheet as possible (Bindseil, 2014).

The rationale behind the lean balance sheet was to minimize the intermediation role of the central bank and related potential market distortions. At the limit, financial assets should simply mirror banknotes on the liability side of the central bank's balance sheet.

But institutional arrangements do matter. Prior to the crisis, the Federal Reserve (Fed) dealt with a small number of counterparties and mostly held Treasuries directly on its balance sheet. By contrast, the lack of a single fiscal issuer and a fragmented banking sector along national lines required that the ECB carried out repos with a broad range of counterparties against a broad range of collateral. Irrespective of the different operational arrangements, central bank balance sheets on both sides of the Atlantic have grown rapidly since the onset of the crisis, and the reasons behind this growth provide useful lessons for the post-crisis world. ${ }^{2}$

Beyond the justifications provided by the crisis for the use of the size and composition of central banks' balance sheets as policy instrument, there are good arguments to preserve the instrument in the policy toolkit. They stem from some structural changes that have occurred in financial markets. In particular, the increased role of secured money market transactions; the importance of a broad set of market rates

\footnotetext{
${ }^{2}$ For a broad overview of the impact of the ECB asset purchase programme, see Andrade et al. (2016).
} 
beyond the overnight rate, in view of imperfections in arbitrage; the growing relevance of non-bank institutions in market-based finance; and finally, the scarcity of safe assets that affects the functioning of markets and the management of collateral.

These developments are behind proposals recently presented in Jackson Hole by Duffie and Krishnamurthy (2016) and by Greenwood, Hanson, and Stein (2016) which stress the importance of the Fed's reverse repo program (RRP).

In the first paper, the program would be used to involve more counterparties and affect several interest rates, thereby contributing to a better transmission of monetary policy, in view of the limits to arbitrage hampering the pass-through from short- to long-term interest rates. Recent internal work at the ECB also detects similar pass-through imperfections in European markets. In the paper by Greenwood et al. (2016), RRP is considered a way to create very short-term safe assets. It would foster financial stability by avoiding the unsuccessful attempts by the private sector to fulfill that role, as we saw before the crisis.

Both arguments deserve careful consideration although they are, from a European perspective for the moment, less relevant or less urgent. In fact, the enduring, predominantly bank-based nature of the European financial system allows us to consider the possibility of going back, once the situation is normalized, to lending to banks as the main channel for managing liquidity and steering short-term interest rates. Nevertheless, the structural changes that I just mentioned are also growing in Europe, and we have to reflect on the possible limitations of monetary policy transmission by only influencing the very short end of money-market rates.

Better benchmark rates are needed, ideally relying on actual transaction data to improve their reliability and robustness. Yet, moves to improve benchmarks suffer at present from the challenge of declining transaction volumes in the unsecured interbank market although the ongoing work points to a successful conclusion of the reform.

The discussion of which interest rates to focus on is closely intertwined with the issue of central bank counterparties. The ECB has traditionally granted a broad range of financially sound credit institutions access to monetary policy operations. That approach enabled us to swiftly 
provide liquidity to various financial market segments during the crisis where more active central bank intermediation was warranted. Nevertheless, non-banks are beginning to play a greater role in the European financial landscape and are likely to take an even greater role as the Capital Markets Union deepens and broadens financial markets in Europe.

Such a consideration is not neutral for market rates in the euro area. Secured money market rates, backed by high-quality collateral, have for a while been trading well below the ECB deposit facility rate, which normally sets a floor for short-term money market rates. In part, this discount is explained by non-banks' activities that - not having access to central bank facilities - are accepting interest rates below the deposit facility rate. The discount is, of course, also attributed to the Asset Purchase Programme, which has reduced the availability of high-quality collateral at the same time as market demand for that collateral has increased. Nonetheless, understanding these drivers is crucial for the central bank when making decisions about future counterparty eligibility and the choice of money market rates used to assess monetary policy transmission.

In this perspective, the path followed in the US will be of great importance for our reflections on the other side of the Atlantic.

\section{Conclusion}

Let me conclude. A number of potential changes to monetary policy frameworks could be necessary to meet the challenges of the new economic environment. I provided my thoughts on some of them, but omitted many others. Other challenges stem from a prolonged period of low, albeit not negative, interest rates resulting from the decline in potential growth and the demographic effects on savings (Fischer, 2016).

Indeed, the apparent difficulties to reach higher levels of inflation and real equilibrium interest rates may hamper the capacity of monetary policy to deal with future recessionary episodes (Yellen, 2016).

Some economists maintain that monetary policy can do almost everything, even if it would require the use of very negative rates, either because they are against the use of fiscal policy or because they genuinely believe in some form of new monetarism. Central bankers should, however, avoid such hubris and accept that, at present, the contributions of 
fiscal, regulatory, and competition policies are necessary to foster investment and improve the supply side of our economies. In view of the dimension of the challenges the world faces, I think this word of humility is a good coda for a central bank talk.

Thank you for your attention.

\section{References}

Andrade, P., J. Breckenfelder, F. De Fiore, P. Karadi and O. Tristani (2016) “"The ECB's asset purchase programme: an early assessment," ECB Working Paper No. 1956.

Bean, C. (2009). "The meaning of internal balance thirty years on," The Economic Journal, 119, pp. 442-460.

Benhabib, J., S. Schmitt-Grohé and M. Uribe (2001). “The perils of Taylor rules," Journal of Economic Theory, 96, pp. 40-69.

Bindseil, U. (2014), "Monetary policy operations and the financial system," Oxford U. P., p. 30 for a short discussion on the concept.

Blanchard, O., G. Dell'Ariccia and P. Mauro (2010). "Rethinking macroeconomic policy," IMF Staff Position Note, 12 February SPN 10/03; Krugman, P. (2014). "Inflation targets reconsidered," ECB Forum on Central Banking Monetary Policy in a changing financial landscape; Krugman, P. (2012). "Two per cent is not enough," The New York Times, 26 January.

Duffie, D. and A. Krishnamurthy (2016). "Pass-through efficiency in the FED's new monetary policy setting," and Greenwood, R., S. Hanson and J. Stein (2016). "The Federal Reserve's balance sheet as a financial stability tool," both presented at the Jackson Hole Economic Policy Symposium, Federal Reserve Bank of Kansas City.

Fischer, S. (2016). "Why are interest rates so low? Causes and implications," remarks at the Economic Club of New York, October; Gagnon, E., B. K. Johannsen and D. López-Salido (2016). "Understanding the new normal: the role of demographics," Federal Reserve Board Finance and Economics Discussion Series, 2016-2080.

Goodfriend, M. (2016). "The case for unencumbering interest rate policy at the zero lower bound," Jackson Hole Economic Policy Symposium, Federal Reserve Bank of Kansas City.

Meade, J. (1978). "The meaning of internal balance," The Economic Journal, 88, pp. 423-435.

Rogoff, K. (2016). “The Curse of Cash,” Princeton University Press.

Rostagno, M., U. Bindseil, A. Kamps, W. Lemke, T. Sugo and T. Vlassopoulos (2016). "Breaking through the zero line: the ECB's negative interest rate policy," 
Brookings Institution, Washington D.C., 6 June. Presentation available on the Brookings Institution website.

Svensson, L. E. O. (1997). "Inflation forecast targeting: Implementing and monitoring inflation targets," European Economic Review, 41(6), pp. 1111-1146.

Svensson, L. E. O. (2003). "What is wrong with Taylor rules? Using judgement in monetary policy through targeting rules," Journal of Economic Literature, 41, pp. 426-477.

Woodford, M. (2012). "Methods of policy accommodation at the interest-rate lower bound," Jackson Hole Economic Policy Symposium, Federal Reserve Bank of Kansas City on 31 September 2012.

Yellen, J. (2016). “The Federal Reserve's monetary policy toolkit: past, present and future," remarks at the Jackson Hole Economic Policy Symposium, Federal Reserve Bank of Kansas City; Reifschneider, D. (2016). "Gauging the ability of the FOMC to respond to future recessions," Federal Reserve Board Finance and Economics Discussion Series, 2016-2068. 